\title{
NOTES
}

\section{AN ARGUMENT FOR THE ADMISSIBILITY OF EXECUTION IMPACT EVIDENCE IN PENNSYLVANIA}

\author{
Paige H. Forster ${ }^{*}$
}

\section{INTRODUCTION}

In 1991, the United States Supreme Court made a significant change to sentencing proceedings during capital trials. ${ }^{1}$ The Court ruled in Payne $v$. Tennessee that the Eighth Amendment does not prohibit "victim impact evidence," testimony about the character of the murder victim and the impact of the death on the victim's family. ${ }^{2}$ The Payne decision permits highly emotional testimony from family members ${ }^{3}$ to enter into the penalty phase of a death penalty trial. ${ }^{4}$

During the penalty phase, the sentencer (usually a jury) has already found the defendant guilty of first-degree murder and is considering whether the sentence should be death or life in prison. ${ }^{5}$ This determination is made by weighing mitigating circumstances against aggravating circumstances relating

* J.D. Candidate 2006, University of Pittsburgh School of Law. The author wishes to express gratitude for the help and encouragement of Professor Welsh S. White and respectfully dedicates this article in his memory.

1. John H. Blume, Ten Years of Payne: Victim Impact Evidence in Capital Cases, 88 CornelL L. Rev. 257, 281 (2003).

2. Payne v. Tennessee, 501 U.S. 808, 827 (1991)

3. Wayne A. Logan, When Balance and Fairness Collide: An Argument for Execution Impact Evidence in Capital Trials, 33 U. Mich. J.L. Reform 1, 27 (1999).

4. Payne, 501 U.S. at 811.

5. See, e.g., 42 PA. Cons. Stat. Ann. § 9711(a)(1) (West 1998). 
to the crime or the defendant's prior history. ${ }^{6}$ In Pennsylvania, aggravating circumstances are limited to those enumerated in the capital sentencing statute, such as killing a police officer, killing during the commission of a felony, or killing by means of torture. ${ }^{7}$ To counter the aggravating evidence, the U.S. Supreme Court has ruled that a defendant has the "broadest latitude" to present mitigating evidence to the jury. ${ }^{8}$ The Pennsylvania statute accordingly allows defendants to show any one of a list of mitigating circumstances (e.g., no significant criminal history, extreme mental or emotional disturbance, relative youth $)^{9}$ or "[a]ny other evidence of mitigation concerning the character and record of the defendant and the circumstances of his offense." 10

The majority opinion in Payne stated that admitting Victim Impact Evidence was a way to redress the imbalance in capital trials, which had become "unfairly weighted" in favor of the defendant. ${ }^{11}$ The decision allows the prosecution to present a broader range of evidence at the penalty phase, which, the Court said, is only fair since "virtually no limits are placed on the relevant mitigating evidence a capital defendant may introduce." 12

Defense attorneys have attempted to respond to Victim Impact Evidence by presenting "execution impact evidence," ${ }^{3}$ which consists of information about how the convicted individual's death by execution would affect his or her family. ${ }^{14}$

The states that use the death penalty have responded fairly consistently to the Payne ruling. ${ }^{15}$ A recent survey found that of the thirty-eight death penalty states, thirty-one permit the use of Victim Impact Evidence in a fairly broad fashion, two place significant restrictions on the use of Victim Impact Evidence, and five have yet to consider its admissibility. ${ }^{16}$

By contrast, there is no clear consensus among state courts on the question of Execution Impact Evidence. In most of the death penalty states,

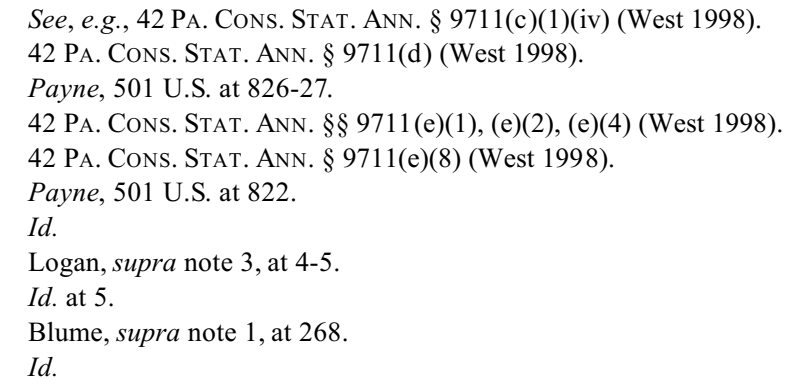


Execution Impact Evidence is not admissible, although it is permitted in at least seven states. ${ }^{17}$

Pennsylvania follows the majority of states with regard to its law on Victim Impact Evidence and Execution Impact Evidence. Victim Impact Evidence is specifically authorized through language in the Pennsylvania capital sentencing statute. ${ }^{18}$ Execution Impact Evidence, on the other hand, was ruled inadmissible by the Pennsylvania Supreme Court in 2002 because it is "irrelevant" to the questions at issue during the sentencing phase. ${ }^{19}$

This Note will argue that, since Pennsylvania permits Victim Impact Evidence, fairness requires that Execution Impact Evidence be permitted as well. Part II reviews Pennsylvania's approval of Victim Impact Evidence and its prohibition of Execution Impact Evidence. Part III outlines the ways in which both kinds of evidence can be seen as highly problematic. Part IV argues that the U.S. Constitution requires that Execution Impact Evidence be admitted, despite its potentially troubling nature, to show all possible mitigating circumstances. Part V concludes by emphasizing the need for balance between Victim and Execution Impact Evidence.

\section{Pennsylvania Law on Impact Evidence}

\section{A. Victim Impact Evidence}

In 1995, the Pennsylvania General Assembly amended the state's sentencing statute to explicitly permit Victim Impact Evidence. ${ }^{20}$ Prior to the amendment, the statute read: "In the sentencing hearing, evidence may be presented as to any matter that the court deems relevant and admissible on the question of the sentence to be imposed. Evidence shall include matters relating to any ... aggravating or mitigating circumstances ...." ${ }^{21}$ After the 1995 amendment, the statute reads:

In the sentencing hearing, evidence concerning the victim and the impact that the death of the victim has had on the family of the victim is admissible. Additionally, evidence may be presented as to any matter that the court deems relevant and admissible on the question of the sentence to be imposed. Evidence shall include matters relating to any

17. Logan, supra note 3, at 32-33.

18. 42 Pa. Cons. Stat. Ann. $§ 9711(a)(2)$ (West 1998).

19. Commonwealth v. Harris, 817 A.2d 1033 (Pa. 2002).

20. S. 179-22, 1st. Spec. Sess., at 123-24 (Pa. 1995).

21. 42 Pa. Cons. Stat. AnN. § 9711(a)(2) (West 1982) (amended 1995). 
... aggravating or mitigating circumstances ..., and information concerning the victim and the impact that the death of the victim has had on the family of the victim. ${ }^{22}$

On the Pennsylvania Senate floor, one of the senators who sponsored the bill explained that the amendment would "codify the United States Supreme Court's ... decision in Paine [sic] v. Tennessee that the use of victim impact evidence at the sentencing portion of a criminal trial, particularly for a defendant convicted of first-degree murder, is constitutionally permissible." ${ }^{23}$

In Commonwealth v. Means, the Pennsylvania Supreme Court affirmed the constitutionality of the amended statute under the federal ${ }^{24}$ and state constitutions. ${ }^{25}$ The court held that "Pennsylvania jurisprudence favors the introduction of all relevant evidence during a capital sentencing proceeding. Pennsylvania's sentencing scheme does not limit the evidence admissible in the penalty phase to only the information necessary to establish aggravating and mitigating circumstances. ${ }^{26}$

\section{B. Execution Impact Evidence}

The Means ruling might appear to allow both Victim Impact Evidence and Execution Impact Evidence, as both are arguably relevant. ${ }^{27}$ However, one year later, the Pennsylvania Supreme Court held in Commonwealth $v$. Harris that Execution Impact Evidence is inadmissible. ${ }^{28}$

In Harris, the defendant's family testified during the penalty trial about the defendant's "character and his difficult upbringing," which was relevant under the sentencing statute's "catchall" mitigating factor. ${ }^{29}$ In addition, the

22. 42 Pa. Cons. Stat. Ann. § 9711(a)(2) (West 1998) (emphasis added).

23. Pa. S. Res. 123.

24. Commonwealth v. Means, 773 A.2d 143, 151 (Pa. 2001).

25. Id. at 153 .

26. Id. at 157. Means' precedential value was later questioned since the statute was upheld by a plurality of three justices plus one concurring justice. However, the court has confirmed that Means is sound precedent. Commonwealth v. Rice, 795 A.2d 340, 351 (Pa. 2002).

27. The court held explicitly in Means that "victim impact testimony is just one of the relevant factors the jury may consider." Means, 773 A.2d at 154. Although the court has held that Execution Impact Evidence is irrelevant, Commonwealth v. Harris, 817 A.2d 1033, 1054 (Pa. 2002), other states' courts have taken the opposite view. See, e.g., State v. Manning, No. 03-1982, 2004 La. LEXIS 2981, at *128 (La. Oct. 19, 2004). In addition, commentators have advanced coherent arguments for the relevance of Execution Impact Evidence. See discussion infra Part IV.

28. Harris, 817 A.2d at 1053-54.

29. Id. at 1053. The "catchall" provision permits "[a]ny other evidence of mitigation concerning the character and record of the defendant and the circumstances of his offense." 42 PA. Cons. STAT. AnN. $\S 9711(\mathrm{e})(8)$ (West 1998). 
defendant sought to admit his family's testimony about the effect of his crime on their lives, but the trial court sustained the Commonwealth's objection on grounds of irrelevance. ${ }^{30}$ The Supreme Court upheld the trial court's ruling, stating that the defendant's "'execution impact' or 'third party impact' testimony ... . was not relevant under Pennsylvania's capital sentencing statute," since it "does not fall within any of the seven specific mitigating circumstances" or the "catchall" mitigating circumstance. ${ }^{31}$

Notably, the Harris majority did not directly address the expansive language in Means regarding the types of evidence that are admissible in the sentencing phase. ${ }^{32}$ In a concurring and dissenting opinion, Justice Zappala stated that despite his dissent in Means, he believed that the Means majority opinion signified that both Victim Impact Evidence and Execution Impact Evidence were admissible. ${ }^{33}$

In 2004, the Pennsylvania Supreme Court in Commonwealth v. Hughes took a further step foreclosing the admissibility of Execution Impact Evidence. $^{34}$ The court limited the Means language that Justice Zappala had cited in Harris. ${ }^{35}$ The Hughes court acknowledged that Means stated that relevant evidence during the sentencing phase of a capital trial "was not limited to aggravating and mitigating circumstances," but added that "this pronouncement was in relation to the ability of the Commonwealth to introduce victim impact testimony pursuant to a specific statutory authorization." 36 Therefore, the Hughes court read Means to signify that "[t]he precedent in this area has . . circumscribed admissibility to evidence that tends to establish or rebut statutory eligibility or selection criteria, namely, aggravating or mitigating circumstances and victim impact evidence. ${ }^{\prime 37}$ In other words, to be relevant at the sentencing phase, evidence does not have to fall into the categories of aggravating or mitigating circumstances; but it must fall into one of the categories of eligibility or selection criteria that are listed in the statute. ${ }^{38}$

\footnotetext{
30. Harris, 817 A.2d at $1053-54$.

31. Id. at 1054 .

32. Means, 773 A.2d at 153 .

33. Harris, 817 A.2d at 1059 (Zappala, C.J., concurring and dissenting).

34. Commonwealth v. Hughes, 865 A.2d 761, 798 (Pa. 2004).

35. Id.

36. $I d$.

37. Id. (emphasis added).

38. The defendant's eligibility for the death penalty is determined by the presence of aggravating factors, such as the victim's status as a firefighter or law enforcement official, the commission of murder for pay or by means of torture, or the defendant's "significant history of felony convictions involving the
} 
The portion of the statute that outlines the required jury instructions states that if there is at least one aggravating circumstance, the jury "shall consider, in weighing the aggravating and mitigating circumstances, any [victim impact] evidence." ${ }^{39}$ The Hughes opinion reiterates this point, stating that Victim Impact Evidence is part of the selection decision, together with aggravating and mitigating circumstances. ${ }^{40}$ In Hughes, the court laid out an exhaustive list of the types of evidence that are admissible at the sentencing phase of a capital trial. ${ }^{41}$ By leaving out Execution Impact Evidence, the court stated implicitly — but clearly - that it is not admissible.

Thus, the penalty phase of a capital trial in Pennsylvania is explicitly permitted to include Victim Impact Evidence, ${ }^{42}$ but it may not include Execution Impact Evidence. ${ }^{43}$

\section{The Problems of Victim Impact Evidence and Execution Impact EVIDENCE}

No consideration of Victim Impact Evidence and Execution Impact Evidence could reasonably omit discussion of the problematic nature of both types of evidence. Certainly, Victim Impact Evidence has been thoroughly critiqued in judicial opinions and in the academic literature. ${ }^{44}$ Execution Impact Evidence has received less attention, and less of what has been written about it considers the problems that attend its use. ${ }^{45}$ This section will outline and briefly respond to the criticisms of Victim Impact Evidence, then discuss a few of the problems with Execution Impact Evidence.

\footnotetext{
use or threat of violence.” 42 Pa. Cons. Stat. Ann. § 9711(d) (West 1998). Once eligibility is determined, the selection decision is made as specified in the statute: "[T]he verdict must be a sentence of death if the jury unanimously finds ... one or more aggravating circumstances which outweigh any mitigating circumstances." 42 PA. Cons. STAT. ANN. § 9711(c)(1)(iv) (West 1998).

39. 42 Pa. Cons. Stat. AnN. § 9711(c)(2) (West 1998).

40. Hughes, 865 A.2d at 798 n.41.

41. Id.

42. 42 Pa. Cons. Stat. Ann. § 9711(a)(2) (West 1998).

43. Commonwealth v. Harris, 817 A.2d 1033, 1054 (Pa. 2002).

44. See, e.g., Blume, supra note 1; Logan, supra note 3; Evan J. Mandery, Notions of Symmetry and Self in Death Penalty Jurisprudence (With Implications for the Admissibility of Victim Impact Evidence), 15 Stan. L. \& Pol'y Rev. 471 (2004); Amy K. Phillips, Comment, Thou Shalt Not Kill Any Nice People: The Problem of Victim Impact Statements in Capital Sentencing, 35 Am. Crim. L. Rev. 93 (1998).

45. See, e.g., Payne v. Tennessee, 501 U.S. 808, 845-47 (1991) (Marshall, J., dissenting); Commonwealth v. Means, 773 A.2d 143, 160-62 (Pa. 2001) (Zappala, J., dissenting); Rachel King \& Katherine Norgard, What About Our Families? Using the Impact on Death Row Defendants' Family Members as a Mitigating Factor in Death Penalty Sentencing Hearings, 26 FlA. St. U. L. Rev. 1119 (1999); Logan, supra note 3.
} 


\section{A. Criticism of Victim Impact Evidence}

Criticisms of Victim Impact Evidence can be roughly divided into two categories: substantive and procedural.

\section{Substantive Concerns}

Foremost among the concerns about Victim Impact Evidence is one articulated by Justice Marshall in his Payne dissent: the evidence is problematic precisely because of its focus on the victim and the victim's family. At the sentencing phase, the jury's "constitutionally required task [is to] determin[e] whether the death penalty is appropriate in light of the background and record of the accused and the particular circumstances of the crime." ${ }^{46}$ Victim Impact Evidence instead "draw[s] the jury's attention . . . to such illicit considerations as the eloquence with which family members express their grief and the status of the victim in the community." ${ }^{47}$

Closely related to this substantive objection to Victim Impact Evidence is the concern that it leads irresistibly toward relative valuations of human life that are morally objectionable ${ }^{48}$ not to mention irrelevant to the capital sentencing procedure. The Payne majority dismissed this possibility, stating:

As a general matter, ... victim impact evidence is not offered to encourage comparative judgments ....-for instance, that the killer of a hardworking, devoted parent deserves the death penalty, but that the murderer of a reprobate does not. It is designed to show instead each victim's "uniqueness as an individual human being . . .."49

Nevertheless, as one commentator has noted, the implicit message of Victim Impact Evidence may be strong:

What else could a capital sentencing jury think when presented with detailed evidence about both the defendant and the victim other than that its role is to decide whether the capital defendant ... should be permitted to live when the innocent victim and his or her family have suffered so much $?^{50}$

46. Payne, 501 U.S. at 847 n.1 (Marshall, J., dissenting) (quoting Booth v. Maryland, 482 U.S. 496, 507 (1987)).

47. Id. at 846 (Marshall, J., dissenting).

48. Vivian Berger, Payne and Suffering-A Personal Reflection and a Victim-Centered Critique, 20 Fla. St. U. L. Rev. 21, 48-49 (1992).

49. Payne, 501 U.S. at 823.

50. Blume, supra note 1, at 279. 
Two concerns about the way in which Victim Impact Evidence is presented buttress these objections to its content. First, the evidence is functionally, if not legally, irrebuttable. ${ }^{51}$ Second, it has enormous emotional power. $^{52}$

The difficulty in rebutting Victim Impact Evidence was conceded by the Payne majority, which stated that "the mere fact that for tactical reasons it might not be prudent for the defense to rebut victim impact evidence makes the case no different than others in which a party is faced with this sort of a dilemma." ${ }^{33}$ However, the difficulty in rebutting Victim Impact Evidence may not be simply "tactical." Wayne A. Logan has found instances of legal barriers, such as courts ruling that evidence is inadmissible when it shows that the victim was involved in drugs or had solicited a prostitute. ${ }^{54}$

The emotional power of Victim Impact Evidence amplifies the concerns associated with its permissibility. Stories of murder victims are tragic narratives. ${ }^{55}$ Beyond the inherent power of these narratives is the broad variety of ways in which they have been presented during sentencing phases: through "poems, videotapes, pre-death photographs, and handcrafted items made by the victim.." ${ }^{56}$ It has been argued that Payne "has placed emotion front and center in capital trials," ${ }^{57}$ and it is difficult to overestimate the emotional power of Victim Impact Evidence that can cause a trial judge to weep "openly." 58

These substantive concerns about the power of Victim Impact Evidence and the manner in which it is presented take on particular weight in light of the momentous decision that is being made at a capital sentencing proceeding.

\section{Procedural Concerns}

Two procedural concerns about Victim Impact Evidence are that juries are not provided with sufficient guidance as to its use, and that it does not

\footnotetext{
51. Payne, 501 U.S. at 823; Logan, supra note 3, at 27.

52. Logan, supra note 3, at 27.

53. Payne, 501 U.S. at 823.

54. Logan, supra note 3, at 27 n. 138 .

55. See, e.g., Payne, 501 U.S. at 814-16 (summarizing Victim Impact Evidence presented at Pervis Tyrone Payne's trial); Commonwealth v. Natividad, 773 A.2d 167, 178-79 (Pa. 2001) (summarizing Victim Impact Evidence presented at Ricardo Natividad's trial).

56. Blume, supra note 1, at 271-72 (citations omitted)

57. Logan, supra note 3 , at 45 .

58. Id. at 27 .
} 
level the playing field between prosecution and defense - even assuming that a level playing field is desirable or constitutional. There is a dearth of procedural guidance for the introduction and consideration of Victim Impact Evidence. ${ }^{59}$ The fact that juries frequently are not told how to evaluate Victim Impact Evidence is the source of much criticism, both within Pennsylvania ${ }^{60}$ and around the country. ${ }^{61}$ In Pennsylvania, juries are statutorily required to receive clear instructions that the sentence must be death if aggravating circumstances outweigh mitigating circumstances. ${ }^{62}$ However, with regard to Victim Impact Evidence, they are told only that if there is at least one aggravating and one mitigating circumstance, they "shall consider, in weighing the aggravating and mitigating circumstances, any evidence presented about the victim and about the impact of the murder on the victim's family." ${ }^{63}$ These instructions beg the questions of what exactly Victim Impact Evidence is (an aggravating circumstance or something else?) and precisely how it is to be "considered." 64

Justice Nigro of the Pennsylvania Supreme Court accepts the constitutionality of Victim Impact Evidence itself, but concludes that "Pennsylvania's statutory provisions governing victim impact evidence in the penalty phase of capital cases violate the Due Process Clause of the Fourteenth Amendment to the United States Constitution." ${ }^{65}$ Justice Nigro has laid out a proposed "set of procedural safeguards," including allowing testimony by only one adult relative of the victim and allowing Victim Impact Evidence only if the defendant introduces evidence under the "catchall" mitigator. ${ }^{66}$

A second procedural concern is that Victim Impact Evidence tampers with the constitutional balance between the powers of the state and the rights of the accused. As Justice Stevens stated in his Payne dissent, "The premise that a criminal prosecution requires an evenhanded balance between the State and the defendant is ... incorrect. The Constitution grants certain rights to the criminal defendant and imposes special limitations on the State designed

59. Commonwealth v. Means, 773 A.2d 143, 162 (Pa. 2001) (Nigro, J., dissenting); Blume, supra note 1 , at $275-76$.

60. Means, 773 A.2d at 162 (Nigro, J., dissenting).

61. Blume, supra note 1 , at 275-76.

62. 42 Pa. Cons. Stat. AnN. § 9711(c)(1)(iv) (West 1998).

63. 42 Pa. Cons. Stat. Ann. § 9711(c)(2) (West 1998).

64. Means, 773 A.2d at 162 (Nigro, J., dissenting).

65. Commonwealth v. Rice, 795 A.2d 340, 363-64 (Pa. 2002) (Nigro, J., concurring) (citations omitted).

66. Means, 773 A.2d at 165 (Nigro, J., dissenting). 
to protect the individual from overreaching by the disproportionately powerful State." ${ }^{67}$ This argument calls into question one of the main rationales of the Payne majority's ruling: the desire to redress the "unfairly weighted" scales in a capital trial by relaxing the limits on evidence the State may present. ${ }^{68}$

Evan J. Mandery argues that even if an imbalance exists in capital sentencing, Victim Impact Evidence does not correct it. ${ }^{69}$ Mandery points out that the broad admissibility of mitigating factors increases the likelihood that "a defendant will be unjustly spared." 70 Victim Impact Evidence, on the other hand, increases the chances that a defendant will be unjustly sentenced to death. ${ }^{71}$ "[E]ven if admitting unlimited mitigating evidence is wrong, the admission of victim impact evidence is not a wrong that counteracts the other wrong. It is just another wrong." $" 72$ Mandery argues that if mitigating evidence about the defendant's life creates a real imbalance, the proper solution would be to allow aggravating evidence about the defendant's life. ${ }^{73}$ Victim Impact Evidence does not redress imbalance in a symmetrical fashion. Instead, it introduces another arbitrary factor into sentencing-phase considerations, thus increasing the likelihood that the outcome will be unjust. $^{74}$

These two arguments about balance - that of Justice Stevens and that of Mandery-together create a cogent argumentagainst Victim Impact Evidence. In sum, the argument is that any imbalance in favor of the accused was created intentionally by the U.S. Constitution, and even if we wish to ameliorate the imbalance now, Victim Impact Evidence fails to do the job.

\section{B. Criticism of Execution Impact Evidence}

To say that Victim Impact Evidence has been subjected to a fair amount of criticism is not to say that Execution Impact Evidence is not also problematic. One argument against Execution Impact Evidence follows from

\footnotetext{
67. Payne v. Tennessee, 501 U.S. 808, 860 (1991) (Stevens, J., dissenting).

68. Id. at 822 .

69. Mandery, supra note 44 , at 507-08.

70. Id. at 507 .

71. Id. at 508 .

72. Id. at 507

73. Id. at 508 .

74. Id. at 507-08.
} 
the discussion of symmetry above ${ }^{75}$ another attacks the relevance of the evidence. $^{76}$

\section{Lack of Symmetry}

Advocates of Execution Impact Evidence argue that it is Victim Impact Evidence, not the defendant's freedom to present mitigating circumstances, that has led to an imbalance in capital sentencing. ${ }^{77}$ They contend that the imbalance favors the state rather than the defendant, and that Execution Impact Evidence is the necessary remedy. ${ }^{78}$ However, Mandery's reasoning seems to lead to the conclusion that Execution Impact Evidence only adds another arbitrary factor to the sentencing phase because it fails to directly address Victim Impact Evidence. A direct solution to the problem of Victim Impact Evidence would be to increase the legal and tactical feasibility of rebutting it. ${ }^{79}$

From this viewpoint, Execution Impact Evidence represents another counterproductive maneuver in pursuit of the elusive goal of balance between the accused and the State. Unlimited mitigating evidence represents an arbitrary factor in sentencing proceedings $;{ }^{80}$ Victim Impact Evidence adds a second arbitrary factor $;{ }^{81}$ and Execution Impact Evidence would toss in yet a third. With each step in a potentially endless loop of imbalance and redress, the total odds of an arbitrary or unjust outcome increase.

\section{Lack of Relevance}

In ruling that Execution Impact Evidence is not admissible in Pennsylvania, the Pennsylvania Supreme Court has stated that Execution Impact Evidence is irrelevant. ${ }^{82}$ This conclusion relies on a relatively narrow interpretation of the U.S. Supreme Court's decision in Skipper v. South Carolina $^{83}$

5. See supra text accompanying notes $70-75$.

76. See Commonwealth v. Harris, 817 A.2d 1033, 1054 (Pa. 2002).

77. Logan, supra note 3 , at 4.

78. Id. at 5 .

79. See supra text accompanying notes 54-55 (summarizing the difficulties in rebutting Victim Impact Evidence).

80. Mandery, supra note 44, at 507.

81. Id. at 508

82. Commonwealth v. Harris, 817 A.2d 1033, 1054 (Pa. 2002).

83. 476 U.S. 1 (1986). 
In Skipper, the defendant sought to introduce evidence "regarding his good behavior during the over seven months he spent in jail awaiting trial." 84 The Court noted that its precedents required that a defendant not be precluded from introducing, "as a mitigating factor, any aspect of [his] character or record and any of the circumstances of the offense that [he] proffers as a basis for a sentence less than death." 85 Concluding that the evidence was admissible, the Court stated, "Although it is true that any such inferences would not relate specifically to [the defendant's] culpability for the crime he committed, there is no question but that such inferences would be 'mitigating' in the sense that they might serve 'as a basis for a sentence less than death." "\$66 The Court went on to explain that evidence of the defendant's good adjustment to prison was "an aspect of his character that is by its nature relevant to the sentencing determination." $" 87$

In Commonwealth v. Harris, the defendant sought to introduce testimony by his family about how his crime had affected them. ${ }^{8}$ He argued that Skipper mandated the admissibility of this testimony as "relevant mitigation evidence." ${ }^{" 89}$ The majority rejected the defendant's argument. ${ }^{90}$ The opinion distinguished the Harris Execution Impact Evidence from the Skipper character evidence by stating that Execution Impact Evidence has "no bearing on [the defendant's] character or record or the circumstances of the offense.".91

Having concluded that federal law did not require the admissibility of the Execution Impact Evidence, the Harris court stated that admissibility was not required by Pennsylvania's capital sentencing statute because it "does not fall within any of the seven specific mitigating circumstances [or] the 'catchall' mitigating circumstance."92 The "catchall" mitigator, the court explained, "obviously mirrors the requirements of Skipper" to "the defendant's character or record or the circumstances of the crime." 94 Therefore, Pennsylvania's capital sentencing law has no place for Execution Impact Evidence.

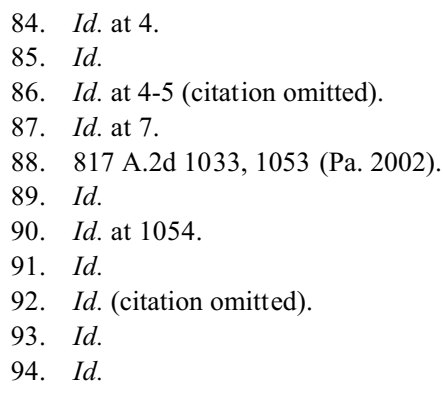


Execution Impact Evidence, like Victim Impact Evidence, is susceptible to attack because it focuses on the impact of the defendant's life on his or her loved ones, rather than the defendant's character or record or the circumstances of the offense. ${ }^{95}$

\section{The Admissibility of Execution Impact Evidence as Character EVIDENCE}

Despite the arguments against Execution Impact Evidence, ${ }^{96}$ this Note argues that it is character evidence and, therefore, admissible under the U.S. Constitution according to the Supreme Court's Skipper decision. Execution Impact Evidence shows the defendant's character through his or her familial relationships. Furthermore, when it is excluded, there is a risk that the resulting gap in information will damage the rest of the defense narrative about the defendant's character or record and the circumstances of the offense. ${ }^{97}$

\section{A. Execution Impact Evidence as Character Evidence}

Execution Impact Evidence is a form of character evidence, the admissibility of which is required by U.S. Supreme Court precedents such as Skipper. ${ }^{98}$ The Oregon Supreme Court followed this line of reasoning in State v. Stevens. ${ }^{99}$ In that case, the defendant's wife had testified about the effect of the defendant's potential execution on their young daughter. ${ }^{100}$ The court reasoned that although this testimony

may not offer any direct evidence about [the] defendant's character or background, it does offer circumstantial evidence. A rational juror could infer from the witness's testimony that she believed that her daughter would be affected adversely by [the] defendant's execution because of something positive about his relationship with his daughter and because of something positive about [the] defendant's character or background. ${ }^{101}$

\footnotetext{
95. Skipper v. South Carolina, 476 U.S. 1, 4 (1986).

96. See discussion supra Part III.B.

97. Skipper, 476 U.S. at 4.

98. King \& Norgard, supra note 45, at 1148.

99. 879 P.2d 162 (Or. 1994).

100. Id. at 164 .

101. Id. at 168 .
} 
The California Supreme Court articulated its approval of Execution Impact Evidence through similar language, stating that it "constitutes indirect evidence of the defendant's character." 102

In holding that Execution Impact Evidence is irrelevant, ${ }^{103}$ the Pennsylvania Supreme Court took a narrow view of what kind of evidence is relevant to the defendant's character or record or the circumstances of the offense. However, a narrow reading is not warranted by U.S. Supreme Court decisions. ${ }^{104}$ The Supreme Court "has repeatedly insisted that states permit unconstrained consideration of "all relevant mitigating evidence." "105 A broad reading fits with the widely accepted idea that capital sentencing is sui generis - a category unto itself. ${ }^{106}$ Because of the extreme significance of the jury's sentencing decision, the law surrounding the death penalty has consistently sought to take into account the individuality of each defendant. ${ }^{107}$ The importance of individualization weighs on the side of admission of evidence about the defendant's character as reflected in his familial relationships.

According to the logic endorsed by courts such as the Oregon and California Supreme Courts, the admissibility of Execution Impact Evidence is required by the Supreme Court's holding that "the sentencer . . . not be precluded from considering, as a mitigating factor, any aspect of a defendant's character or record." 108

\section{B. Execution Impact Evidence as Part of a Narrative Whole}

Wayne A. Logan points out that in a capital trial, it is extremely important for the defense attorney to create a "narrative whole." 109 The U.S. Supreme Court acknowledged the importance of trial narrative in Old Chief $v$. United States:

102. People v. Ochoa, 966 P.2d 442, 505-06 (Cal. 1998).

103. Commonwealth v. Harris, 817 A.2d 1033, 1053-54 (Pa. 2002).

104. See Skipper v. South Carolina, 476 U.S. 1, 4 (1986) (quoting Eddings v. Oklahoma, 455 U.S. 104, 110 (1982)).

105. Logan, supra note 3, at 9 (citing Buchanan v. Angelone, 522 U.S. 269, 276 (1998)).

106. King \& Norgard, supra note 45, at 1144 (quoting Lockett v. Ohio, 438 U.S. 586, 604-05 (1978)).

107. Logan, supra note 3, at 37-38.

108. Skipper, 476 U.S. at 4 (quoting Eddings, 455 U.S. at 110).

109. Logan, supra note 3 , at 47. 
When a juror's duty does seem hard, the evidentiary account of what a defendant has thought and done can accomplish what no set of abstract statements ever could, not just to prove a fact but to establish its human significance, and so to implicate the law's moral underpinnings and a juror's obligation to sit in judgment. ${ }^{110}$

Old Chief referred specifically to the prosecution's prerogative to create a narrative for the jury. ${ }^{111}$ However, the importance of the capital defense attorney's creation of a coherent story at the penalty trial has been well documented. ${ }^{112}$ Defendants who are at risk of being sentenced to death have often committed the most shocking types of murders, and as one capital defense attorney has said, "[P]eople who commit extraordinary crimes have extraordinary backgrounds and are responding to extraordinary circumstances." 113 It is extremely important for the defense attorney to enjoy the same prerogative as the prosecution: the ability to tell a story that will allow the jury to feel empathy for the defendant's circumstances, ${ }^{114}$ which are often unimaginably dreadful. ${ }^{115}$ Presenting evidence about the defendant's history at the proper time, and in the proper manner, can have life and death consequences. ${ }^{116}$

The ability to tell a complete story about the defendant's character and relationships takes on special importance because of the admissibility of Victim Impact Evidence. ${ }^{117}$ Without Execution Impact Evidence, the jury only hears the story of one family's grief and pain. The other family is silenced on this matter, and the narrative gap could lead a jury to draw negative inferences about the defendant's character. ${ }^{118}$ Thus, the exclusion of Execution Impact Evidence may undermine other evidence about the defendant's character and record - evidence that is inarguably admissible under the U.S. Constitution. ${ }^{119}$

110. Old Chief v. United States, 519 U.S. 172, 187-88 (1997).

111. Id. at 188 .

112. See Welsh S. White, The Death Penalty in the Nineties 76-87 (1991).

113. Id. at 86 (quoting Craig Haney regarding the death sentence of David Carpenter).

114. Id. at 79 .

115. See id. at $105-06$.

116. See id. at 80-85 (describing the penalty trial and death sentence of defendant David Carpenter).

117. Logan, supra note 3, at 47.

118. Id. at 49 (quoting Nancy Pennington \& Reid Hastie, Explaining the Evidence: Tests of the Story Model for Juror Decision Making, 63 J. Personality \& Soc. Psychol. 189, 190 (1992)).

119. See Skipper v. South Carolina, 476 U.S. 1, 4 (1986). 


\section{CONCLUSION}

Execution Impact Evidence has come to the fore because the U.S. Supreme Court created a new category of admissible evidence, Victim Impact Evidence, through its decision in Payne v. Tennessee. ${ }^{120}$ The real problem may be the admissibility of Victim Impact Evidence in Pennsylvania, not the inadmissibility of Execution Impact Evidence. ${ }^{121}$ However, there seems to be little reason to hope for an end to Victim Impact Evidence in the near future, ${ }^{122}$ especially since the Pennsylvania General Assembly specifically inserted authorization for Victim Impact Evidence into the state's capital sentencing statute. ${ }^{123}$ Therefore, capital jurisprudence in Pennsylvania must strive toward fairness in a system that includes Victim Impact Evidence.

It could be argued that allowing Execution Impact Evidence only introduces another arbitrary factor into a sentencing procedure that already contains too many opportunities for unjust outcomes. ${ }^{124}$ Nevertheless, court opinions and commentators have cogently advanced the idea that Execution Impact Evidence should be admitted to redress the bias toward the prosecution represented by Victim Impact Evidence. ${ }^{125}$

The emotional power of Victim Impact Evidence, combined with the lack of substantive and procedural limitations on its presentation, have led to the argument that it "creates a seriously imbalanced capital jurisprudence."126 Execution Impact Evidence addresses the imbalance by allowing jurors to consider the impact of the loss of a loved one on the defendant's family as well as the victim's. ${ }^{127}$ Then-Chief Justice Zappala stated the point succinctly in a dissenting opinion: "[B]ecause our Court has opened the door to allow the jury to hear evidence regarding the impact of the victim's death, the door should not now close when the defendant attempts to offer evidence as to the impact the execution will have on his benefactors." 128

120. 501 U.S. 808 (1991).

121. See King \& Norgard, supra note 45, at 1124.

122. Id.

123. See discussion supra Part II.A.

124. See discussion supra Part III.B.1.

125. See Commonwealth v. Harris, 817 A.2d 1033, 1060 (Pa. 2002) (Zappala, C.J., concurring and dissenting); King \& Norgard, supra note 45, at 1125. See generally Logan, supra note 3.

126. Logan, supra note 3, at 14.

127. King \& Norgard, supra note 45 , at 1126.

128. Harris, 817 A.2d at 1060 (Zappala, C.J., concurring and dissenting). 